\title{
Blood meal organic fertilizer application on onion yield
}

\author{
N. Momtaz, A. Parvin, M. K. Hossain*, B. Saha, M. Moniruzzaman, A. Kibria, M. A. M. Sarker \\ and J. L. Munshi
}

Biological Research Division, Bangladesh Council of Scientific \& Industrial Research (BCSIR), Dhaka-1205, Bangladesh

Received: 13 December 2020

Revised: 11 January 2021

Accepted: 31 March 2021

DOI: https://doi.org/10.3329/bjsir.v56i1.54315

\begin{abstract}
In this study, effects of bloodmeal on onion (Allium cepa L. CV. BARI peaj-1) cultivation to increase yield and related attributes have been tested. The effect of blood meal as fertilizers has been compared with growth hormone treatment and other conventional fertilizer. In the field, the different amount of growth elements treated were at the rate of $2550,241.90$ and $0.17 \mathrm{~kg} / \mathrm{ha}$ for blood meal, urea and gibberellic acid $\left(\mathrm{GA}_{3}\right)$, respectively. The yield performance was $172.84,189.59$ and 153.34 $\mathrm{MT} /$ ha for $\mathrm{GA}_{3}$, urea and blood meal, respectively. Using $\mathrm{GA}_{3}$ is expensive, and use of urea, a chemical fertilizer, can have adverse effect on soil. Blood meal, a biological ingredient, appears to be a bio-rationale amendment for production and sustained yield of onion. The results will need to ground truth tested in the field.
\end{abstract}

Keywords: Blood meal; Organic fertilizer; Allium cepa L.; Treatments; Urea; Gibberellic acid; Onion production

\section{Introduction}

Onion (Allium cepa L.) belonging to the Family Alliaceaehave been used as food and flavoring agent from time immemorial. Onion as medicine and preservative in the last couple of decades has become popular due to the rich source of organic sulphur compounds, flavonoids and phenolic acids having antibacterial, antioxidant and hypolipidemic property (Melvin Joe et al., 2009; Srinivasan et al., 2004). Dietary dehydrated onion reduced serum cholesterol with proven hypercholesterolemia properties in rats (Vidyavati et al., 2010). The world production of onion is about 93.22 million MT (FAO, 2019) whereas, in Bangladesh, onion production was 1.83 million MT and 1.09 million MT were imported to meet the local market demand (BBS, 2018). The production of onion in Bangladesh is much lower compared to other onion growing countries like India, Egypt, Iran, etc. In addition, the demand for onion in Bangladesh is growing rapidly due to high consumption.
Research can play an important role in high yielding onion through productivity improvement.

Onions have shallow and rarely branched root system thus require larger supplies of nutrients (Brewster, 2008). Application of inorganic fertilizer is not always feasible due to high cost and the numerous side effects on the soil and soil nutrient and microflora (Falodun et al., 2015). Prolonged application of chemical fertilizer has led to many environmental impacts i.e., overloaded with minerals and nutrients (salinization) in soil, generation of greenhouse gas and eutrophication in water body (da Costa and Passaglia, 2013; Simpson et al., 2011). Recently, Qiu et al., (2020) published an important work regarding the onion production using organic compost and epsom salt. In this work, authors show the positive response of onion yield when applied the combined treatment both compost and chemical fertilizer 
together. On the contrary, blood meal has been recognized as an organic fertilizer (Ciavatta et al., 1997) can play a vital role for growth, development as well as yield of crops. Industrial slaughterhouses produce a large amount of blood as a byproduct. Very little information is available concerning use of blood powder as a source of Fe for plant (Kalbasi and Shariatmadari, 1993). Blood meal is a 10-13\% nitrogen $(\mathrm{N})$ containing organic fertilizer, mainly composed of hemoglobin (globular protein) and characterized by the presence of a prosthetic group (protoporphyrin) containing iron (Fe) (Ciavatta et al., 1997). The Fe content in blood meal is about $0.2-0.3 \%(\mathrm{w} / \mathrm{w})$, but even though this Fe may be taken up by plant roots (Kalbasi and Shariatmadari, 1993), normally this essential micronutrient is not considered declarable for the organic fertilizers by Italian law (Italian Republic Law, 1984).

Plant growth regulators (PGRs), gibberellic acid (GA $)$ has a significant and interesting role in modern agriculture (Ashraf et al., 2010; Hassan et al., 2013). Effects of growth regulators on yield of onion were studied in quite a few studies. One of the studies assessed the effect of growth regulators from their timing of application perspective (Hye et al., 2002). Responses of onion and garlic against plant growth regulators were tested in the study of Ouzounidou et al. (2011). Moreover, in some research works growth regulators were applied with chemical fertilizers (Islam et al., 2007; Behairy et al., 2015) to increase the production of onion. Therefore, to meet the crisis created by any shortage of onion supply, research work should be carried out to optimise the production of onion in Bangladesh. For the purpose, besides the conventional cultivation of onion through the application of chemical fertiliser, the use of blood meal based organic fertilizer might be useful.

In Bangladesh, no research has so far been carried out to evaluate the effect of blood meal to increase the yield of onion and knowledge about the influence of blood meal on soil organic matter and soil fertility is now limited. Therefore, the present research has been undertaken to assess the yield and yield attributes of onion by applying blood meal, and the result is compared with those test results, ran parallel using urea and $\mathrm{GA}_{3}$ as growth promoting agents.

\section{Materials and methods}

The field experiment was conducted at the experimental field of the Biological Research Division, Bangladesh Council of Scientific and Industrial Research (BCSIR) Laboratories, Dhaka. The research was done from December, 2018 to April, 2019.Uniform seedlings (45 days old) of the onion cultivar (BARI peaj-1) were collected from Spice Research Center of Bangladesh Agriculture Research Institute (BARI), Gazipur.
Prior to planting experiment, soil samples were collected from a depth of 0-30 cm using auger. The collected samples were dried in the air, mixed and ground to pass through $2 \mathrm{~mm}$ sieve to remove large particles, debris, and stones. The composite sample was packed in a polythene bag, labeled and taken to Soil and Environment Research Section, Biological Research Division, BCSIR Laboratories, Dhaka. Sample was analyzed for $\mathrm{pH}$, organic carbon, total $\mathrm{N}$, available nitrogen, phosphorus, potassium, sodium, calcium, magnesium, copper, zinc and soil texture. The particle size analysis was done by hydrometer method as described by Gee and Bauder (1986). Textural classes were determined by Marshall's Triangular co-ordinate system. Soil pH was measured (field condition) electrochemically by using glass electrode $\mathrm{pH}$ meter and the ratio of soil to water was $1: 2.5$ (Jackson, 1973). Soil organic matter was determined by wet-oxidation method as outlined by Walkley and Black (1934). Total and available $\mathrm{N}$ was determined by the Kjeldahl procedure as described by Jackson (1973). Phosphorus was analyzed colorimetrically by the Olsen method using UV visible Spectrophotometer, (Model: Analytikjena, Specord 205) as described by Jackson (1973). Sodium and potassium were determined on flame photometer (Model: Jenway, PFP7). All other metals were analyzed using atomic absorption spectrophotometer (Shiamdzu, AA7000).

The experiment was laid out in randomized complete block design (RCBD) with two replications. The unit plot size was $3.36 \mathrm{~m}^{2}$ and distance between two plots maintained as $0.37 \mathrm{~m}^{2}$. A Factorial Design (FD) of 3 factors :(1)- blood meal, (2)-urea, (3)-GA $\mathrm{GA}_{3}$ with 2 levels (given and not given) has been used in the study. Two replications were considered for application of each treatment. In a total, 16 plots were used to apply all the treatments and treatment combinations. The 16 treatments were $\mathrm{GA}_{3}, \mathrm{GA}_{3}+\mathrm{Blood}$ meal+Urea, GA + Urea, $\mathrm{GA}_{3}+$ Blood meal, Blood meal, GA, Urea, Control, Blood meal+Urea, Urea, Blood meal+Urea, $\mathrm{GA}_{3}+\mathrm{Urea}$, Blood meal, GA + Blood meal, GA +Blood meal+Urea, Control. Blood meal, urea and $\mathrm{GA}_{3}$ were applied 2550, 241.90, 0.17 $\mathrm{kg} / \mathrm{ha}$ in the field, respectively. The experimental control contained no blood meal, urea and $\mathrm{GA}_{3}$.

Each plot was applied cowdung (20kg/plot) during the experimental bed preparation as basal. Drip irrigation system was used. The dosage of blood meal and urea were selected on the basis of nitrogen content for the growth and yield of onion (Kamble and kathmale, 2015). The full amounts of organic fertilizer blood meal $(2550 \mathrm{~kg} / \mathrm{ha})$ and urea $(241.90$ $\mathrm{kg} / \mathrm{ha}$ ) were applied at 20 days after transplanting. $\mathrm{GA}_{3}$ was sprayed in $0.17 \mathrm{~kg} / \mathrm{ha}$ at three times. The first one was after 30 days of transplanting and then every 15 days for the 
second and third spray. All the intercultural operations such as watering, weeding, mulching, etc. were done as and when necessary.

A random sample of 10 onion plants were taken from each experimental plot at 120 days after transplanting date and transferred to the laboratory to measure the number of leaves/plant; length of leaves bulb; length of neck; weight of leaves, fresh weight bulb and bulb diameter. The production data were converted into MT/ha.

Descriptive statistics of growth parameters (number of leaves, length of leaves and length of neck) and yield parameters (bulb diameter, fresh bulb weight) of onion were measured and computed. Descriptive statistics, mean and standard deviation (SD) were calculated first. Then in order to test the equality of these parameters of onion, analysis of variance (ANOVA) was performed. All of the parameters varied significantly $(\mathrm{p}<0.05)$. Finally, Duncan Multiple Rank Test (DMRT) of Post Hoc series of tests was performed. Statistical software, SPSS of its version 16.0 was used for data analysis.

\section{Results and discussion}

The result of the chemical analysis of soil before planting has

Table I. Nutrient content with neutral pH experimental plot. Textural classification of this plot belongs to sandy clay loam soil

\begin{tabular}{lc}
\hline \multicolumn{1}{c}{ P arameters } & Results \\
\hline Organic matter $(\mathrm{OM})$ & $1.5 \pm 0.02$ \\
Total Nitrogen, $\mathrm{TN}(\%)$ & $0.04 \pm 0.01$ \\
Available nitrogen, N (mg/kg) & $79.3 \pm 2.1$ \\
Phosphorous, P (mg/kg) & $0.45 \pm 0.01$ \\
Potassium, K (mg/kg) & $21.3 \pm 1.2$ \\
Sodium, Na (mg/kg) & $20.3 \pm 1.0$ \\
Calcium, Ca (mg/kg) & $135.2 \pm 3.0$ \\
Magnesium, $\mathrm{Mg}(\mathrm{mg} / \mathrm{kg})$ & $242.9 \pm 4.0$ \\
Copper, Cu $(\mathrm{mg} / \mathrm{kg})$ & $4.08 \pm 0.01$ \\
Zinc, $\mathrm{Zn}(\mathrm{mg} / \mathrm{kg})$ & $7.5 \pm 0.03$ \\
\hline
\end{tabular}

been depicted in Table I. The organic matter content in neutral soil was $1.5 \%$. Total $\mathrm{N}$ content of the soil was $0.04 \%$. Available nitrogen, phosphorus and potassium content of the soil was $79.3,0.45,21.3 \mathrm{mg} / \mathrm{kg}$, respectively. Experimental soil also contained $\mathrm{Ca}, \mathrm{Mg}, \mathrm{Zn}, \mathrm{Cu}, \mathrm{Na}$ and its values were $135.2,242.9,7.5,4.08,20.3 \mathrm{mg} / \mathrm{kg}$, respectively.

Growth parameters of onion plants like number of leaves per plant, length of leaves and length of neck were measured after 120 days of plantation. The data have been presented in Table II which showed that all treatments produced better results than control plots (Table II). The highest number of leaves (11.43) was obtained from single application of blood meal and the lowest number of leaves (9.50) was grown by onion plant from the control (Table II). Number of leaves is highest in single treatment than combination in most cases. The leaf length of onion was found the tallest $(51.20 \mathrm{~cm})$ when urea was used as a single fertilizer and the shortest number of leaves $(46.20 \mathrm{~cm})$ was from the control. Maximum length $(6.90 \mathrm{~cm})$ of neck in onion was observed when blood meal and urea used together and control provided minimum length $(5.65 \mathrm{~cm})$ of neck. In Table I, DMRT shows that the number of leaves vary significantly for different individual and combined treatments. Length of leaves and length of neck do not differ significantly at 5\% level of significance.

Weight of leaves and yield of onion after applying different treatments are presented in Table III. Weight of leaves was affected by different treatments. The maximum weight of leave (46.75 MT/ha) was obtained by the application of blood meal, urea and $\mathrm{GA}_{3}$ and the minimum weight of leave (19.62 MT/ha) was obtained by the control. Leaves weight was increased in combined treatment than single treatment. A highly significant difference in the bulb yield per hectare was found due to the effect of blood meal, urea and GA . Urea produced the highest yield $189.59 \mathrm{MT} / \mathrm{ha}$ followed by $\mathrm{GA}_{3}(172.84 \mathrm{MT} / \mathrm{ha})$ and blood meal (153.34 MT/ha). The lowest yield was 131.24 MT/ha in untreated control. In case of combination, blood meal and urea gave the highest yield (172.79 MT/ha) followed by blood meal and $\mathrm{GA}_{3}(140.60$ $\mathrm{MT} / \mathrm{ha}$ ) and the lowest (130.08 MT/ha) yield was found in urea and $\mathrm{GA}_{3}$. 159.36 MT/ha was obtained by the application of blood meal, urea and $\mathrm{GA}_{3}$.

Table IV depicts the comparison of organic (blood meal) and chemical fertilizer (urea), hormone $\left(\mathrm{GA}_{3}\right)$ in bulb yield (MT /ha) of onion. In all treatment, bulb yield is significantly increased compared to the control. Chemical fertilizer shows the highest percentage in yield (71.91\%) over control (Lee, 2010). However, it has long term adverse effect in crop field. Afterwards, growth hormone (GA, IAA) signifies a lot to increase bulb yield (Hye et al., 2002; Islam et al., 2007 and 
Table II. Growth of onion plants in different treatments

\begin{tabular}{lccc}
\hline Treatment & No. of leaves & $\begin{array}{c}\text { Length of leaves } \\
(\mathrm{cm})\end{array}$ & $\begin{array}{c}\text { Length of neck } \\
(\mathrm{cm})\end{array}$ \\
\cline { 2 - 4 } & Mean \pm SD & Mean \pm SD & Mean \pm SD \\
\hline Control & $9.50 \pm 2.43^{\mathrm{c}}$ & $46.20 \pm 4.87^{\mathrm{c}}$ & $5.65 \pm 1.16^{\mathrm{b}}$ \\
$\mathrm{GA}_{3}$ & $10.17 \pm 1.47^{\mathrm{b}}$ & $47.17 \pm 4.36^{\mathrm{b}}$ & $6.40 \pm 0.93^{\mathrm{ab}}$ \\
Urea & $10.00 \pm 0.89^{\mathrm{b}}$ & $51.20 \pm 7.19^{\mathrm{a}}$ & $6.35 \pm 1.53^{\mathrm{ab}}$ \\
Blood meal & $11.43 \pm 0.53^{\mathrm{a}}$ & $47.50 \pm 1.00^{\mathrm{b}}$ & $6.00 \pm 1.55^{\mathrm{ab}}$ \\
$\mathrm{GA}_{3}+$ Urea & $10.83 \pm 1.60^{\mathrm{ab}}$ & $47.20 \pm 3.35^{\mathrm{b}}$ & $6.33 \pm 1.29^{\mathrm{ab}}$ \\
GA $_{3}+$ Blood meal & $11.00 \pm 0.87^{\mathrm{b}}$ & $49.80 \pm 5.63^{\mathrm{b}}$ & $6.77 \pm 1.45^{\mathrm{ab}}$ \\
Blood meal+Urea & $9.66 \pm 0.52^{\mathrm{c}}$ & $48.80 \pm 3.27^{\mathrm{b}}$ & $6.90 \pm 1.47^{\mathrm{a}}$ \\
GA $_{3}+$ Blood meal + Urea & $10.00 \pm 0.63^{\mathrm{b}}$ & $51.00 \pm 4.47^{\mathrm{a}}$ & $5.96 \pm 0.95^{\mathrm{ab}}$ \\
\hline
\end{tabular}

* Means containing the same letter do not differ significantly at $5 \%$ level of significance

Table III. Yield of onion plantation in different treatments

\begin{tabular}{lcc}
\hline Treatment & $\begin{array}{c}\text { Weight of leaves } \\
(\mathrm{MT} / \mathrm{ha})\end{array}$ & $\begin{array}{c}\text { Yield } \\
(\mathrm{MT} / \mathrm{ha})\end{array}$ \\
\cline { 2 - 3 } & $\begin{array}{c}\text { Mean } \pm \text { SD } \\
\text { Control }\end{array}$ & Mean \pm SD \\
GA3 & $35.80 \pm 11.91^{\mathrm{ab}}$ & $131.24 \pm 38.53^{\mathrm{d}}$ \\
Urea & $39.36 \pm 22.92^{\mathrm{ab}}$ & $189.59 \pm 32.65^{\mathrm{a}}$ \\
Blood meal & $31.11 \pm 11.79^{\mathrm{b}}$ & $153.34 \pm 19.97^{\mathrm{bc}}$ \\
GA3+ Urea & $31.53 \pm 12.26^{\mathrm{b}}$ & $130.08 \pm 33.48^{\mathrm{d}}$ \\
GA3+Blood meal & $34.12 \pm 9.52^{\mathrm{b}}$ & $140.60 \pm 24.85^{\mathrm{cd}}$ \\
Blood meal+Urea & $34.33 \pm 11.52^{\mathrm{b}}$ & $172.79 \pm 30.56^{\mathrm{ab}}$ \\
GA3+Blood meal+Urea & $46.75 \pm 19.18^{\mathrm{a}}$ & $159.36 \pm 33.64^{\mathrm{bc}}$ \\
\hline
\end{tabular}

* Means containing the same letter do not differ significantly at $5 \%$ level of significance

our study), although it is not feasible economically. On the contrary, blood meal, wastage from slaughter house, provides $32.33 \%$ increment in bulb yield of onion.

Fig. 1. Depicts the comparison on the effect of treatment and treatment combinations in bulb diameter $(\mathrm{cm})$ of onion. The bulb diameter varies from 16.0-19.2 cm. The highest value was obtained when urea was used and it was $19.21 \mathrm{~cm}$ and the lowest diameter was found when combination of urea and gibberellic acid was applied. The bulb diameter was 17.34 $\mathrm{cm}$ from application of blood meal individually. On the other hand, treatment combinations showed comparatively lower diameter than single treatment.

When compared, production of onion by using only blood meal (153.34 MT/ha) is not satisfactory with $\mathrm{GA}_{3}(172.84$ 
Table IV. Comparison of bulb yield of onion in various treatments from present study with other reported in the literature

\begin{tabular}{llcc}
\hline Reference & Treatment & $\begin{array}{c}\text { Bulb yield } \\
\text { (MT/ha) }\end{array}$ & $\begin{array}{c}\text { Bulb yield increased } \\
\text { over control (\%) }\end{array}$ \\
\hline Present study & Control & 18.74 & --- \\
& GA $_{3}$ & 25.90 & 38.20 \\
& Urea & 25.35 & 35.27 \\
Hye et al., 2002 & Blood meal & 24.80 & 32.33 \\
& Control & 13.59 & --- \\
Islam et al., 2007 & GA & 15.52 & 14.20 \\
& IAA & 14.73 & 8.38 \\
Lee, 2010 & GABA & 12.39 & --- \\
& Control & 14.89 & 20.18 \\
\hline
\end{tabular}

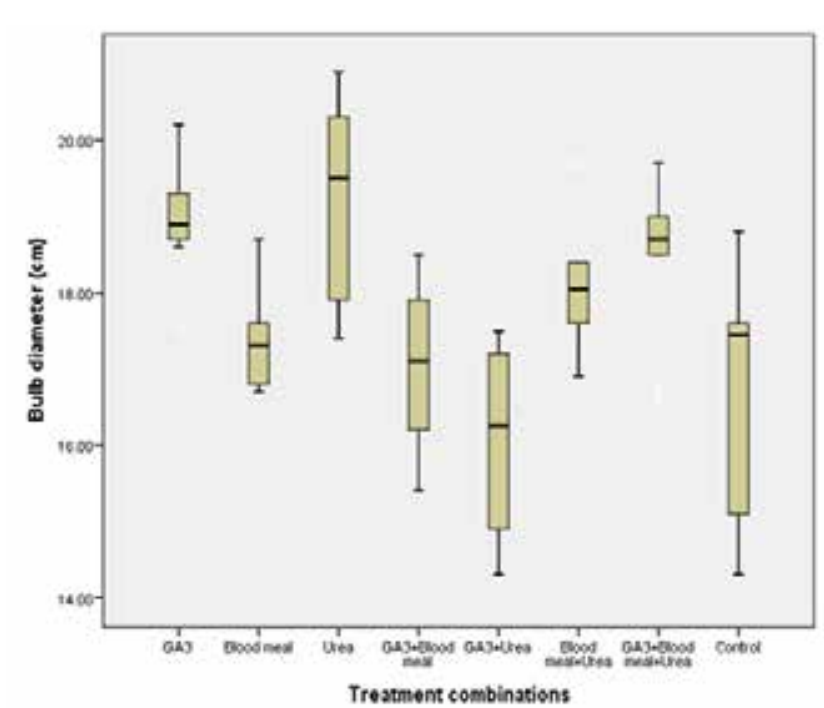

Fig. 1. Effect of treatment and treatment combinations in bulb diameter $(\mathrm{cm})$

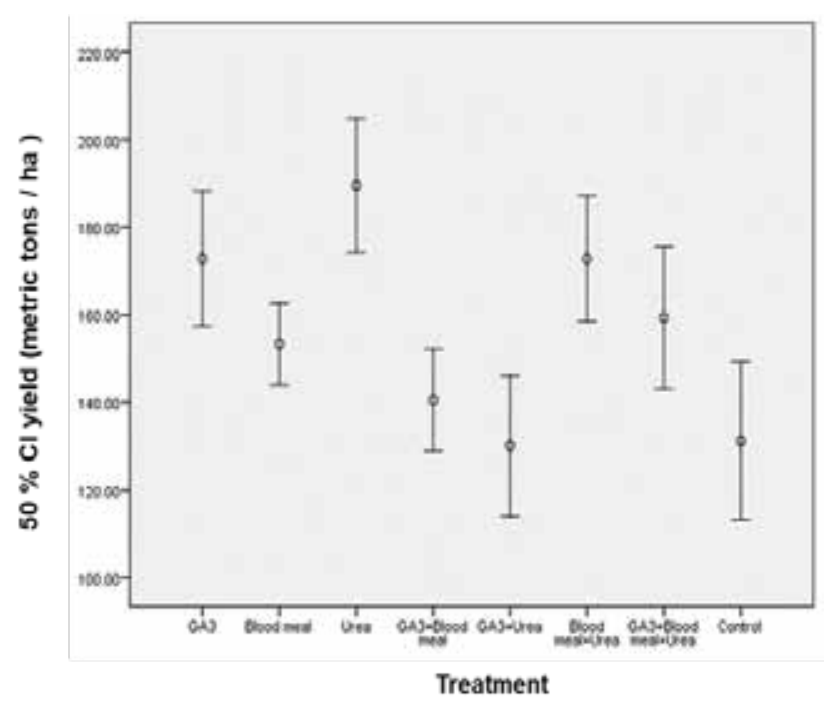

Fig. 2. Average of yield (MT/ha) with $95 \%$ confidence interval (CI) 
MT/ha) and urea (189.59 MT/ha). However, when blood meal was used in combination of urea, the yield is increased (172.79 MT/ha) compared to other treatment combinations except urea individually. $\mathrm{GA}_{3}$ when applied single, the production of onion was $172.84 \mathrm{MT} /$ ha (Fig. 2.).

Now, in order to show the effect of all the treatment combinations on yield of onion per plot, regression analysis was performed. The linear regression line is as follows:

Yield $=2.1100+0.0775 \mathrm{GA}_{3}+0.0263$ blood meal +0.0062 urea $+0.0237 \mathrm{GA}_{3} *$ blood meal $+0.1663 \mathrm{GA}_{3} *$ urea +0.650 blood meal *urea $+0.1800 \mathrm{GA}_{3}$ *blood meal *urea.

Effect of inorganic fertilizer (urea) and organic fertilizer (blood meal) as well as their combinations has been shown in the regression equation. The model is significant $(\mathrm{p}<0.05)$ with $\mathrm{R}^{2}=75.08 \%$ and Adjusted $\mathrm{R}^{2}=53.28 \%$. The model shows that comparatively the effects of all two are similarly individual but the combined effects of blood meal with urea are higher than any other combination of treatments.

The organic carbon content in soil is medium according to rating of Maria and Yost (2006), as they stated that organic carbon content less than $1.5,1.5-2.5$ and $>2.5 \%$ are classified as low, medium and high, respectively. The soil had neutral $\mathrm{pH}$ according to Bruce and Rayment (1982). The $\mathrm{pH}$ value in between 6 and 8 is favorable for onion growth (Nikus and Mulugeta, 2010). Total $\mathrm{N}$ content of the soil is rated as medium according to Tekalign et al. (1991). Available phosphorus content of the soil is very low according to Olsen (1954). who stated that the available phosphorus in soil less than $5,5-9,10-17,18-25$ and $>25 \mathrm{mg} \mathrm{kg}^{-1}$ are grouped as very low, low, medium, high and very high, respectively. Application of blood meal and urea increases onion growth as nitrogen content is medium in the experimental soil.

Application of $\mathrm{N}$ in the form of blood meal or urea increased number of leaves through biochemical processes which in turn enhance vegetative growth. Bungard (1999) suggested that nitrogen, fundamental cell components, plays an important role in all living tissues of the plant and thus developing healthy plant growth. Al-Fraihat and Ahmad (2009) stated that nitrogen is an essential element for the growth of onion through build-up of protoplasm and proteins, which influence cell division as well as meristematic activities.

The chemical fertilizer accumulates large amount of total $\mathrm{N}$ and $\mathrm{P}_{2} \mathrm{O}_{5}$ than organic fertilizer. Nutrient uptakes are top in chemical fertilization than organic fertilizer (Lee, 2010). The addition of organic fertilizer decreased the vegetative growth of plants regarding length of leaves and neck of leaves and bulb diameter and yield of bulb. The organic fertilizer however, enhanced number of leaves. In addition, combination of urea and blood meal increased yield. Sullivan et al. (2001) indicated that approximately 110 $\mathrm{kg} / \mathrm{ha}$ of nitrogen, potassium and calcium, and minimum quantities of phosphorus, sulfur, and magnesium is taken up by onion plants. In Bangladesh, particularly eastern hilly areas, lucrative onion production can be achieved by addition of $165 \mathrm{~kg} \mathrm{~N}, 174 \mathrm{~kg} \mathrm{~K} \mathrm{~K}_{2} \mathrm{O}$ and $30 \mathrm{~kg} \mathrm{~S}$ along with

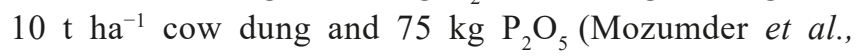
2007). Therefore, application rate of fertilizer is one of the important factors for profitable onion production.

Organic fertilizer enhances availability of nutrient, soil pH and microbial densities (Clark et al., 1998; Dinesh et al.,2000; Reganold, 1988). In the same way, blood meal increases plant available nutrients and enhanced soil physical and biological properties (Datt et al., 2003).

On the other hand, individual application of $\mathrm{GA}_{3}$ increases yield and yield attributes of onion below urea and above blood meal because exogenous application of $\mathrm{GA}_{3}$ enhances physiological process in plant (Saha, 2009). Although $\mathrm{GA}_{3}$ (popular plant growth regulator) is well known to increase yield and yield attributes of onion globally, it is highly expensive, and hence increase the market price of onion, hits the low income consumer.

The property of the soil organic matter has changed initially as blood meal is applied to soil. Addition of $75 \%$ of the organic $\mathrm{C}$ and $78 \%$ of the organic $\mathrm{N}$ has loss due to the mineralization of the organic matter. By the time being, blood meal converted organic material into humic substances therefore, the characteristics of blood meal driven organic matter and original soil organic matter is almost similar. Available Mg and especially Fe increased. The application of the blood meal to the soil increase the availability of different nutrients as blood meal contains different amounts of macro and micro nutrient elements (Ciavatta et al., 1997).

Initially onion yield is below in blood meal than urea and $\mathrm{GA}_{3}$. However, gradually blood meal increases yield without deteriorating soil. Besides, use of urea, chemical fertilizer, has very adverse effect on soil. Finally, the effect of blood meal has been found beneficiary for the production of onion economically and environmentally in Bangladesh. 


\section{Acknowledgments}

Authors thank would like to the Bangladesh Council of Scientific and Industrial Research (BCSIR) authorities for their approval of R\&D project and financial support.

\section{References}

Ashraf M, Akram NA, Arteca RN and Foolad MR (2010), The physiological, biochemical and molecular roles of brassinosteroids and salicylic acid in plant processes and salt tolerance, Crit. Rev. Plant Sci. 29(3): 162-190. DOI: org/10.1071/BT9950093

Al-Fraihat $H$ and Ahmad $H$ (2009), Effect of different nitrogen and sulphur fertilizer levels on growth, yield and quality of onion (Allium cepa L.), Jordan J. Agri. Sci. 5(2): 155-65.

BBS (Bangladesh Bureau of Statistics) (2018), Statistics and Informatics Division (SID), Ministry of Planning.

Behairy AG, Mahmoud AR, Shafeek MR, Ali AH and Hafez MM (2015), Growth, yield and bulb quality of Onion plants (Allium cepa L.) as affected by foliar and soil application of potassium, Middle East Agr. Res. 4(1): 60-66.

Brewster JL (2008), Onions and other vegetable Alliums, CAB International, Wellesborne, UK.

Bruce RC and Rayment GE (1982), Analytical methods and interpretations used by the Agricultural Chemistry Branch for soil and land use surveys, Queensland Department of Primary Industries Bulletin QB82004 CIMMYT. 198

Bungard RA, Wingler A, Morton JD and Andrews M (1999), Ammonium can stimulate nitrate and nitrite reductase in the absence of nitrate in Clematis vitalba, Plant Cell Environ. 22: 859-66. DOI: org/10.1046/j. 1365-3040.1999.00456.x

Ciavatta C, Govi M, Sitti L and Gessa C (1997), Influence of blood meal organic fertilizer on soil organic matter: A laboratory study, J. Plant Nutri. 20(11): 1573-1591. DOI: org/10.1080/01904169709365358

Clark MS, Horwath WR, Shennan C, and Scow KM (1998), Changes in soil chemical properties resulting from organic and low-input farming practices, Agron. J. 90: 662-671. DOI: org/10.2134/agronj1998.00021 $962009000050016 x$ da Costa PB and Passaglia LMP (2013), The effects of different fertilization conditions on bacterial plant growth promoting traits: Guidelines for directed bacterial prospection and testing, Plant Soil. 368: 267-280. DOI: 10.1007/ s00253-009-2196-0

Datt N, Sharma RP and Sharma GD (2003), Effect of supplementary use of farmyard manure along with chemical fertilizers on productivity and nutrient up-take by vegetable pea (Pisum Sativum Var Arvense) and buildup of soil fertility in Lahaul valley of Himachal Pradesh, Indian J. Agri. Sci. 73: 266-268.

Dinesh R, Dubey RP, Ganeshamurthy AN and Prasad GS (2000), Organic manuring in rice-based cropping system: effects on soil microbial biomass and selected enzyme activities, Curr. Sci.79: 1716-1720.

FAO (Food and Agriculture Organization) (2019), Production year book, Rome, Italy.

Falodun EJ, Ehigiator JO and Ogedegbe SA (2015), Growth and yield response of Soyabean (Glycine max Merr.) to organic and inorganic fertilizer in Edo rainforest of Nigeria, American J. Plant Sci. 6: 3293-3297. DOI: 10.4236/ajps.2015.619321

Gee GW and Bauder JW (1986), Particle Size Analysis In: Methods of Soil Analysis, Part A, Ed. Klute, $2^{\text {nd }}$ Ed., Vol. 9. Am. Soc. Agron., Madison, WI. pp 383-411. DOI: org/10.2136/sssabookser 5.4.c12

Hassan NMK, Shafeek MR, Saleh SA, and EL-Greadly NHM (2013), Growth, yield and nutritional values of Onion (Allium cepa L.) plants as affected by bio-regulators and vitamin $\mathrm{E}$ under newly reclaimed lands, App. Sci. Res. 9(1): 795-803.

Hye MA, Haque MS and Karim MA (2002), Influence of growth regulators and their time of application on yield of Onion, Pakistan J. Bio. Sci. 5(10): 1021-1023.

Italian Republic Law(1984), Nuove norme per la disciplina deifertilizzanti., Gazzetta Ufficiale No. 305, $6^{\text {th }}$ November, Rome, Italy.

Islam S, Islam MO, Alam MN, Alam MK, Ali MK and Rahman MA (2007), Effect of Plant Growth Regulator on Growth, Yield and Yield Components of Onion, Asian J. Plant Sci. 6(5): 849-853. DOI: org/ 10.3923/ajps.2007.849.853 
Jackson ML (1973), Soil chemical analysis, Prentice Hall India Pvt. Ltd, New Delhi.

Kalbasi M and Shariatmadari H (1993), Blood powder, a source of iron for plants, Plant Nutri. 16(11): 2213-2223. DOI: org/10.1080/ 01904169309364681

Kamble BM and Kathmale DK (2015), Effect of different levels of customized fertilizer on soil nutrient availability, yield and economics of onion, J. App. Nat. Sci. 7(2): 817-821

Lee J (2010), Effect of application methods of organic fertilizer on growth, soil chemical properties and microbial densities in organic bulb onion production, Sci.Hor. 124: 299-305. DOI: org/10. 1016/j.scienta.2010.01.004

Maria RM and Yost R (2006), A survey of soil fertility status of four agro ecological zones of Mozambique, Soil Science 171(11): 902-914. DOI: 10.1097/01.ss.0000228058.38581.de

Melvin JM, Jayochitra J and Vijayapriaya M (2009), Antimicrobial activity of some common spices against certain human pathogens, J. Med. Plants Res. 3:1134-1136. DOI: org/10.5897/JMPR.9000167

Mozumder SN, Moniruzzaman M and Halim GMA (2007), Effect of $\mathrm{N}, \mathrm{K}$ and $\mathrm{S}$ on the yield and storability of transplanted onion (Allium cepa L.) in the hilly region, J. Agri. Rural Dev. 5(1\&2): 58-63. DOI: https://doi.org/10.3329/jard.v5i1.1459

Nikus O and Mulugeta F (2010), Onion seed production techniques. A manual for extension agents and seed producers. FAO. Crop Diversification \& Marketing Development Project, Asella.

Ouzounidou G, Giannakoula A and AsfiMand IliasI (2011), Differential responses of Onion and Garlic against plant growth Regulators, Pak.J. Bot. 43(4): 2051-2057.

Olsen SR (1954), Estimation of available phosphorus in soils by extraction with sodium bicarbonate, Circ. 939. U.S. Dep. Agric., Washington DC.
Reganold JP (1988), Comparison of soil properties as influenced by organic and conventional farming systems, American J. Altern. Agric. 3: 144-155.

Saha P (2009), Effect of NAA and GA3 on yield and quality of tomato (Lycopersiconesculentum Mill), Environ. Ecol. 27: 1048-1050.

Sullivan DM, Brown BD, Shork CC, Horneck DA, Stevens RG, Pelter GQ and Feibert EBG ( 2001), Nutrient management for onions in the pacific northwest. Pacific Northwest Extension publications, pp 2-7.

Srinivasan K, Sambaiah K and Chandrasekhara N ( 2004), Spices as beneficial hypolipidemic food adjuncts: A review, Food Rev. Int. 20: 187-220. DOI: org/10.1081/FRI-120037160

Simpson RJ, Oberson A, Culvenor RA, Ryan MH, Veneklaas EJ, Lambers H, Lynch JP, Ryan PR, Delhaize E, Smith FA, Smith SE, Harvey PR and Richardson AE (2011), Strategies and agronomic interventions to improve the phosphorus-use efficiency of farming systems, Plant Soil 349: 89-120.

Tekalign T, Haque I and Aduayi EA (1991), Soil, plant, water, fertilizer, animal manure and compost analysis, Working document, (13).

Vidyavati G, Manjunatha H, Hemavathy J and Srinivasan K (2010), Hypolipidemic and antioxidant efficacy of dehydrated onion in experimental rats, J. Food Sci. Technol. 47: 55-60.

Walkley A and Black IA (1934), An examination of Degtjareff method for determining soil organic matter and a proposed modification of the chromic acid titration method, Soil Science 37: 29-37.

Qiu Z, Esan EO, Ijenyo M, Gunupuru LR, Asiedu SK and Abbey L (2020), Photosynthetic activity and onion growth response to compost and Epsom salt, Int. J. Veg. Sci. 26(6): 535-546 DOI: 10.1080/19315260. 2019.1671570 . 

